\title{
Milia like lesions in a 21 year male of hypohidrotic ectodermal dysplasia
}

\section{Ritu Rani, Samriti Sood, Mudita Gupta, Reena K. Sharma}

\author{
Department of Dermatology, Venereology and Leprosy, Indira Gandhi Medical College Shimla, Himachal Pradesh, India
}

Corresponding author: Dr. Samriti Sood, E-mail: drsamritisood0956@gmail.com

\begin{abstract}
Ectodermal dysplasia are rare genetic disorders characterized by abnornomality in development of skin and its appendages. Depending upon the involvement of eccrine gland they can be divided into different variants. Absence/ decreased development of eccrine glands leads to hypohidrotic ectodermal dysplasia. This disorder can be associated with the number of other abnormal morphological features. Milia like plaques have been rarely reported. We present a 2 lyear male of hypohidrotic ectodermal dysplasia who presented with milia like lesions on the face and scalp.
\end{abstract}

Key words: Ectodermal dysplasia; Hypohidrotic; Milia like lesion

\section{INTRODUCTION}

Ectodermal dysplasia (ED) as the name suggests are inherited abnormalities of structures derived from ectoderm i.e. skin hair, teeth, sweat glands and nails [1]. Depending on the involvement of eccrine gland they may be hidrotic or anhidrotic/hypohidrotic. We are presenting a 21 year old male of hypohidrotic ectodermal dysplasia who presented with alopecia, absence of teeth along with rarely reported milia like lesions on the face.

\section{CASE REPORT}

A 21 year old male born to non consanguineous parents by an uneventful normal vaginal delivery with decreased scalp and body hair since birth and history of recurrent febrile seizures. He noticed lesions on the face for past 2-3 years which were asymptomatic and white in color. He also complained of lack of development of teeth. His intellect was normal. Younger brother had similar complaints according to the patient but his sister was normal. There was no history of similar complaints in any of the other family member. On general physical examination he was of average built (height of $159 \mathrm{~cm}$ and weight of $51.4 \mathrm{~kg}$ ). His mental, physical and sexual development was normal. On examination of the face, there was periorbital hyperpigmentation, saddle nose deformity and multiple variable sized papules and plaques studded with milia like lesions (Fig. 1). The hairs on the scalp and beard were sparse, brittle and lusterless with complete loss of eyebrows (Fig. 2). Body hairs were absent. Generalized ichthyosis was present. (Fig. 3). There was decreased dermatoglyphics. Intraoral examination revealed only two peg shaped teeth (right upper incisors) with loss of alveolar ridges and eversion of lips(Fig. 4). Nail and genitalia were normal. On audiometry and eye examination, nothing abnormal was detected. Based on history and clinical examination final diagnosis of hypohidrotic ectodermal dysplasia was made.

\section{DISCUSSION}

Ectodermal dysplasias (ED) are rare inherited disorders with a incidence of $1: 10^{5}[2]$. They are defined by primary abnormal morphogenesis of skin, its appendages and teeth. Thurnam in 1848 first reported a case of ED but the term was coined by Weech in 1929 [3]. There are now more than 192 types of ED which have been classified into 2 major types: hypohidrotic/anhidrotic type and hidrotic type. Hypohidrotic/anhidrotic ED

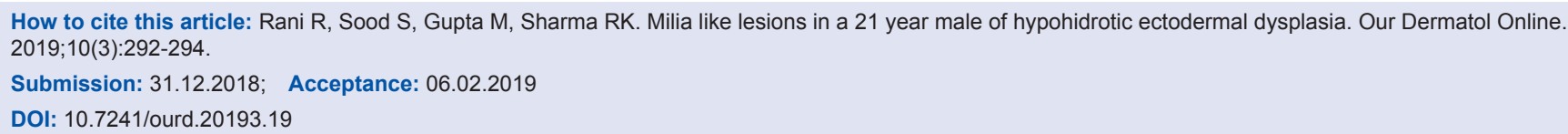




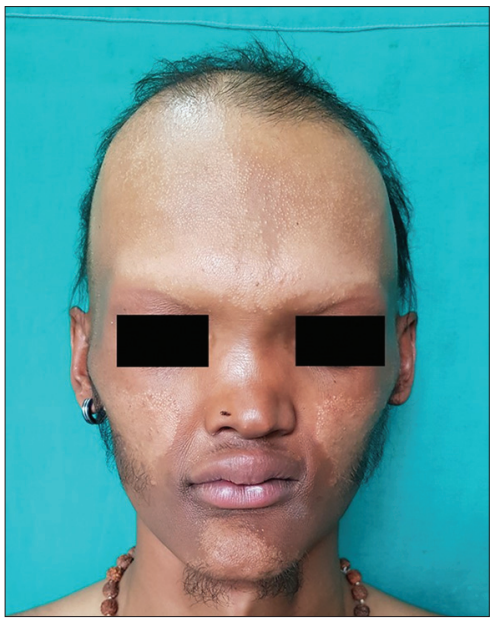

Figure 1: Milia like lesions, saddle nose and absence of eyebrows.

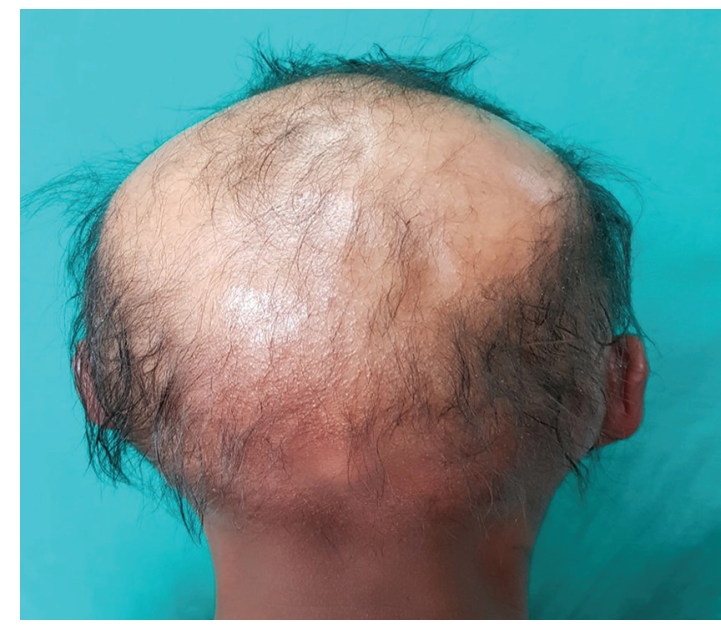

Figure 2: Sparse, thin hairs over scalp with milia like lesions.

(HED) is also known as Christ-Seimens- Touraine syndrome which can be $\mathrm{X}$ linked recessive, autosomal dominant or autosomal recessive, of which $\mathrm{X}$ linked recessive variant is the commonest [4].

Clinically HED along with paucity of eccrine glands has hair abnormalities like hypotrichosis with fine, slowgrowing scalp and body hair, eyelashes and eyebrows. Dental anomalies are characterized by anodontia/ hypodontia in both deciduous and permanent teeth. Teeth are usually conical or peg shaped. Nail though less frequently involved, onychodysplasia may rarely be seen. Skin is thin, wrinkled, dry, with loss of appendages, flexural eczema, peri-orbital hyperpigmentation, saddle nose. Rarely milia like papules may be seen on the face. Dermatoglyphics are reduced. Spock ears may be seen [5]. Patient usually presents at the age of 11-18 yrs. [6].

HED has to be differentiated from Werner syndrome and odonto-onycho-dermal dysplasia. Werner syndrome

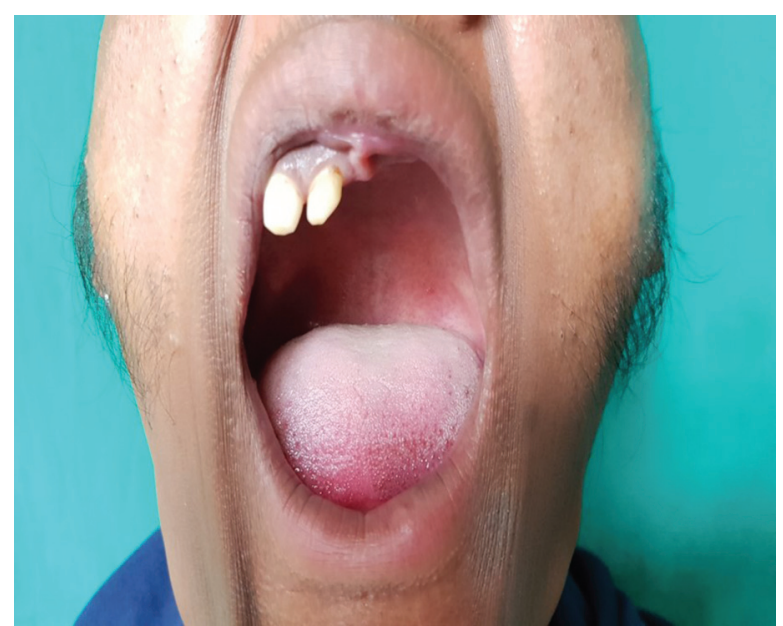

Figure 3: Hypodontia with only two persistent peg shaped teeth.

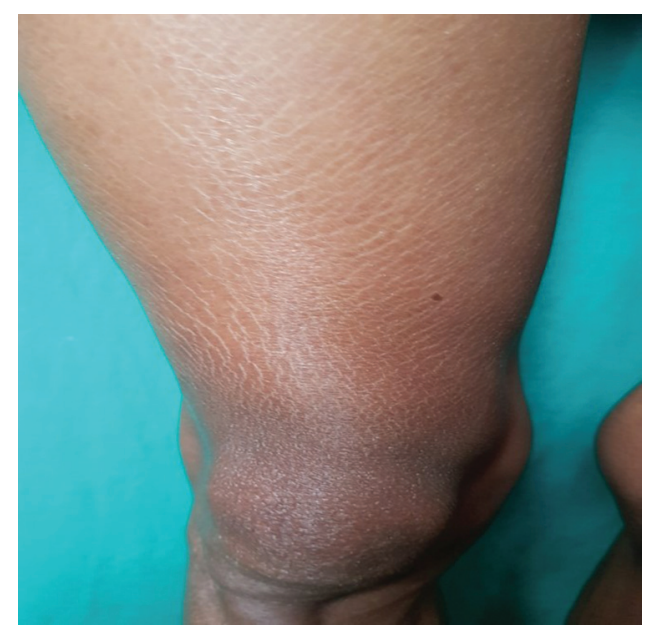

Figure 4: Ichthyosis over thighs.

shows features of premature ageing but hypohidrosis is not a feature and sclerosis is seen. Odonto-onychodermal dysplasia may have hypodontia, sparse hair, onychodysplasia but have hyperhidrosis of palms and soles.

Genetic evaluation in HED have shown gene locus on Xq11-21.1 mutations. Ectoderm-endoderm interaction is required for formation of various ectodermal structures. Mutations in the genes coding for proteins which are required in signaling these pathways leads to ED. Mutations in EDA (ectodysplastin A, a TNF family ligand), EDAR (ectodysplastin A receptor) and EDARADD (ectodysplastin A receptor associated death domain) genes have been identified to cause HED [7].

A patient of HED, in addition to the psychological support patient needs to be counselled about the risk of hyperthermia because cooling effect due to impaired 
sweating is lost [8]. Symptomatic treatment is otherwise given for the rest of the clinical manifestations.

\section{Consent}

The examination of the patient was conducted according to the Declaration of Helsinki principles.

\section{REFERENCES}

1. Meshram GG, Kaur N, Hura KS. A case report of hypohidrotic ectodermal dysplasia: A mini-review with latest updates. J Family Med Prim Care. 2018;7:264-6.

2. Singh GP, Saxena V. Hypohidrotic ectodermal dysplasia. Med J Armed Forces India. 2014;71:530-3.

3. Weech AA. Hereditary ectodermal dysplasia. (Congenital ectodermal defect). Am J Dis Child. 1929;37:766-90.
4. Bani M, Tezkirecioglu AM, Akal N, Tuzuner T. Ectodermal dysplasia with anodontia: a report of two cases. Eur J Dent. 2010;4:215-22.

5. Agarwal S, Gupta S. Hypohidrotic ectodermal dysplasia. Indian Dermatol Online J. 2012;3:125-7.

6. Itin P. Ectodermal dysplasia. In: Griffiths C, Barker J, Bleiker T, Chalmers R, Creamer D eds. Rook's Textbook of dermatology, $9^{\text {th }}$ ed. Wiley- Blackwell publishing 2016. p Griffiths C, Barker J, Bleiker T, Chalmers R, Creamer D.67.12.

7. Vaidya S, Risbud M, Kshar A, Ramdurg P. Hereditary ectodermal dysplasia: Report of 11 patients from a family. Indian J Dent Res. 2013;24:502-6.

8. Srivastava VK. Ectodermal Dysplasia: A Case Report. Int J Clin Pediatr Dent. 2011;4:269-70.

Copyright by Ritu Rani, et al. This is an open-access article distributed under the terms of the Creative Commons Attribution License, which permits unrestricted use, distribution, and reproduction in any medium, provided the original author and source are credited.

Source of Support: Nil, Conflict of Interest: None declared. 